\title{
The European Employment Price Index: Implementation and Feasibility in Austria
}

\author{
Martin Zagler $^{\mathrm{a}, \mathrm{c}}$ and Ulrike Mühlberger ${ }^{\mathrm{b}}$

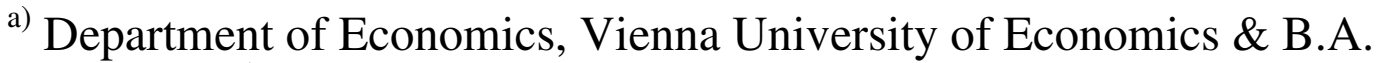

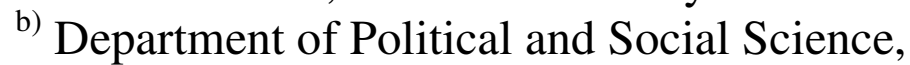 \\ European University Institute, Florence \\ ${ }^{c)}$ Ludwig Boltzmann Institute for Growth Research, Vienna
}

\begin{abstract}
The study, on which this paper is based upon, has analyzed the implementation and feasibility of the European Employment Price Index (EEPI) in Austria. The European Employment Price Index is a Laspeyres measure of the change in the demand-transaction price of the standardized unit of labor. We find that it is feasible to construct the index with the available company data with an approximate lag length of five month. Most data were easily accessible within firms, with the exception of severance payments, company pensions, and hypothetical costs. Only 228 observations are required to obtain an aggregate EEPI for Austria within +/- one percentage point at the $95 \%$ significance level, whilst some 4800 observations are necessary for disaggregate series, enormously increasing costs of provision.
\end{abstract}

Zusammenfassung: Die Studie, auf welcher dieser Artikel basiert, hat die Durchführbarkeit und Sinnhaftigkeit eines Europäischen Arbeitspreisindex für Österreich untersucht. Der Europäische Arbeitspreisindex (EEPI) ist ein Laspeyres-Maß der Veränderung des Nachfrage-Transaktionspreis einer standardisierten Einheit Arbeit. Aufgrund der in Unternehmen vorhandenen Daten ist es möglich, den Index mit einer Verzögerung von ungefähr fünf Monaten zu konstruieren. Der Großteil der Daten war einfach verfügbar, mit der Ausnahme von Abfertigungen, Firmenpensionen und hypothetischen Kosten. Es benötigt nur 228 Beobachtungen um einen aggregierten EEPI für Österreich mit einer Abweichung von +/- $1 \%$ zum $95 \%$ Signifikanzniveau zu generieren, während etwa 4800 Beobachtungen notwendig sind, um disaggregierte Reihen $\mathrm{zu}$ erhalten, wodurch die Kosten enorm steigen würden.

Keywords: Laspeyres Indices, Employment Costs, Cost-Benefit-Analysis, Empirical Survey.

\section{Introduction}

When economists discuss the labor market, they usually have in mind a supply and a demand schedule for labor, where the price of labor, the wage rate, and the quantities of 
labor-supplied by individual households and demanded by other economic agents (firms in particular) - form the two dimensional space. These theoretical simplifications exhibit at least three major shortcomings. First, labor is not homogenous, but supplied in different qualities, both in the vertical direction-more or less skilled workers-and in the horizontal direction due to specialization. This directly leads to the problem of aggregating costs of production, as relative price changes will induce changes in different quantities demanded. We find that a first degree homogenous, isoelastic production technology is the benchmark case for an theory-based index of employment costs. Second, we find that the instantaneous price paid for the unit of labor, may differ from the fictive spot-market price, labeled employment costs, because of the length of the work contract, due to intertemporal adjustments in wage payments. Whilst training costs are repaid in the form of lower wages in subsequent periods, company pension schemes and severance payments are paid in advance by workers, again in the form of lower wages in preceding periods. Third, the labor market is not a typical market where demand meets supply, but is embedded in a rigid institutional framework. The price of labor therefore is not only driven by supply and demand factors, but also by the negotiations of employers and organized labor. All of these factors are important to consider when discussing employment cost measures, as they set out the theoretical concept for the subsequent measurement.

\section{Definitions}

The European Employment Price Index is supposed to be one element in an integrated system of European earnings and labor costs statistics. The European Employment Price Index is a Laspeyres measure of the change in the demand-transaction price of the standardized unit ${ }^{1}$ of labor ${ }^{2}$, following the conventional formula,

$$
\mathrm{EEPI}=\sum_{i} \frac{w_{t}^{i} L_{0}^{i}}{w_{0}^{i} L_{0}^{i}},
$$

where $\mathrm{i}$ is the index over all individual cells, time is indexed by $\mathrm{t}$, with zero being the base year, $w$ represents a particular cost component, and $\mathrm{L}$ is the quantity that this component made use of. The individual cell $i$ will be the standardized hour worked at a particular job. The individual cell lies in a four-dimensional vector space, with a regional dimension (formed by the European NUTS 1 classification, with Austria being devided into three NUTS regions), an industrial sectoral dimension (with 22 categories following the NACE Rev. 1), an occupational dimension (with all 8 categories from the one-digit ISCO-88 (COM) classification, and finally a cost component dimension, with 17 categories of direct and indirect labor costs. Note that the EEPI can be divided into subindices according to the four above mentioned dimensions.

The EEPI as defined above is a theory-consistent indicator of employment cost, adhering to the orthodox neo-classical model of the labor market. It correctly measures the change in all costs that accrue when hiring an additional unit of labor, including intertemporal costs. Moreover, it makes the distinction between price and quantity effects. Finally, it allows for regional, sectoral and occupational subindices. 
The main theoretical advantage of the EEPI, however, is its stability ${ }^{3}$ in relation to other indicators of employment costs ${ }^{4}$. This is due to three reasons. First, the EEPI measures only the changes in the price of labor, holding quantities constant. Both the number of workers as well as specific working hours are held constant, stabilizing the time series over the business cycle. Second, the EEPI includes intertemporal employment costs, as mentioned above, eliminating volatility due to excessive firing in recessions and excessive hiring in a business boom. Finally, whilst most of the volatility in other indicators (e.g. unit wage costs) is due to productivity fluctuations ${ }^{5}$, the EEPI uses at most a partial input measure of productivity. Note that the basic unit of the EEPI is the job, not the worker. If a worker becomes more productive (e.g. due to formal training or learning on the job) and therefore receives a higher wage, she may also get promoted. In this case, she would drop out of the sample, leaving unaffected the evolution of the EEPI. But as the firm receives more „efficiency units“ of labor, hence it is the quantity of labor that changes, not the price. A Laspeyres index should evidently not reflect this change.

\section{Scope}

The EEPI has several distinct practical advantages as compared to other measures of employment costs.

- As a theory-consistent measure of employment costs, it may help rescuing the economic model of the labor market.

- An index subdivided by professions would allow the individual worker to compare her salary with those of her colleagues working under similar conditions, to see whether she is receiving the market wage, below or above it. It would also be interesting to compare ones earnings with the rest of the labor forces to see whether the job choice was correct, and for new entrants to the labor market to guide their choice of career.

- For the wage bargaining partners, the index would yield data on wages actually paid, in contrast to the currently available information on collective bargaining minimum wages, providing an indicator on the stance of wage policy.

- Firms would profit from the EEPI for two additional reasons. On the one hand, it gives a signal on the expected price structure of their competitors (and thus on their choice of supply), as wages are a significant component of production costs (and less observable then the user cost of capital, which is driven by the real rate of interest). Subindicators by sector would certainly improve its usefulness. On the other hand, employment cost indicators are an important indicator when making or revising locational decisions. This information will be available for the first time for all of Europe, which is an important factor in a more and more globalized economy.

- Fifth, the public sector, and the tax payer, too, should have an interest in the EEPI. As nominal output of the public sector is not observable in most cases, the public sector cannot pay marginal product wages. It seems natural to pay public sector employees similar wages as their private sector counterparts, as productivity probably progresses in a similar way. Moreover, the EEPI may serve 
as a leading indicator for policy institutions. Whilst central bankers may appreciate an early warning instrument of cost-push inflationary pressures ${ }^{6}$, fiscal institutions require information on changes in disposable income and its distribution to estimate changes in aggregate demand and subsequently set fiscal policy accordingly. Regional indicators may serve as an indicator for regional development programs, such as the EU structural funds. A regional and occupational distinction will help to detect the tightness of individual segmented labor markets.

In our opinion, the EEPI therefore fulfills, more than any other indicator on employment costs, the criteria of an employment cost indicator.

\section{Survey Design}

The empirical part of the analysis was conducted in three steps. The first stage comprised a series of qualitative interviews in firms. The second stage was aimed at testing the questionnaire to be used in subsequent surveys. After rewriting the questionnaire, we started the third stage in the summer of 1997. This final stage of the empirical analysis surveyed weights for 1996 and employment costs for the first and second quarter of 1997.

The questionnaire consisted of two separate parts. A two page company questionnaire was to be filled out only once for the company. It asked for the sector, the province, the classification of professions and the respective number of employees as well as for the number of effective working days. The core of the survey, a two page professions questionnaire was to be filled out for once for every profession. It started with statistical questions on the permanency, the part-time status and the age. From then on, all data were to be filled out for the average or the typical employee in a specific profession with the specific statistical characteristica defined above. ${ }^{7}$ The questionnaire moreover contained questions on the quality and availability of the data. The main focus was on relevance, accuracy, quality and availability of the data. Moreover, the survey focused at identifying specific Austrian characteristics of the data.

The sample involved 101 firms from six sectors, in six provinces (all three NUTS regions), with one to five professions in each company. The following table gives the distribution of the companies by Sector and Province. The last column presents the summary statistics for the 271 occupational groups.

\begin{tabular}{lr|lr|lr}
$\begin{array}{l}\text { Number of Enterprises } \\
\text { Surveyed by Sectors }\end{array}$ & \multicolumn{2}{c}{$\begin{array}{l}\text { Number of Enterprises } \\
\text { Surveyed by Province }\end{array}$} & \multicolumn{2}{c}{$\begin{array}{l}\text { Number of Employees } \\
\text { Surveyed by Profession }\end{array}$} \\
\hline \hline Building and Construction & 30 & Lower Austria & 10 & Managers & 30 \\
Electrical Supply & 17 & Salzburg & 21 & Service/Sales workers & 41 \\
Financial Intermediation & 12 & Styria & 9 & Professionals & 7 \\
Mechanical Engineering & 13 & Upper Austria & 22 & Craft Workers & 52 \\
Textiles & 15 & Vienna & 35 & Technicians & 28 \\
Tourism & 8 & Vorarlberg & 4 & Machine Operators & 29 \\
Others & 6 & & & Clerks & 62 \\
& & & & Elementary Occupations & 22
\end{tabular}




\section{Main Results on Feasibility}

It is feasible to construct the index with the available data with an approximate lag length of five month. Most data were easily accessible within firms, with the exception of severance payments, and company pensions, which are not very common, however. First, several companies were altogether unable to give clear indication on their reserves for severance payments for the individual employee. Sometimes the data were back from 1995, as the company balance for 1996 were due in the second quarter of 1997. For those companies who had accurate data, these underestimated actual costs, as firms could only build reserves up to $50 \%$, depending on the seignority of the employee. It therefore appears reasonable to obtain severance payments by theoretical approximations.

A more serious problem encountered were hypothetical costs. If companies would pay overtime over the year, whilst no overtime was actually taken in the observation month, the firm was required to give hypothetical costs. If firms were not able to indicate those costs, we approximated them by adding the overtime premium to the hourly cost. Similar problems appeared with sickness days and other non-working days, though to a lesser extent.

Another major problem is the possibility of empty cells. The question is whether to replace the costs by the previous costs of the corresponding employees, implying a growth rate of zero, or to replace it by an average of similar workers within that profession, within that sector or within the province. We have answered the problem with a simple, but powerful econometric regression. From the randomized sample, we have taken $20 \%$ of the data and computed the corresponding series for the sector average, profession average, and province average, using all data except those $20 \%$. We have repeated this procedure for the next $20 \%$ of the observations, until all data entered the regression.

$$
T C=\underset{0,38}{0,567+0,40} \underset{2,459}{\sec \text { tor }}+\underset{1,03}{0,296} \text { state }-\underset{-0,03}{0,008 \text { profession }} \quad \mathrm{R}^{2}: 3,7 \%
$$

We find that the sector average is the only significant series to approximate total compensation. This implies that when the information on sectoral averages is available, adding information on the profession or province does not improve the result.

The quality of the index may basically suffer for the following reasons. First, the selection of the sample can be biased. Even if the companies contacted are selected at random, the response may not, as maybe smaller companies respond less than big, companies with low costs more likely than companies with high costs, or vice-versa. The next scope of error is at the collection of data. In particular, in order to reduce compliance costs, firms might give estimates of the data only. We found that the majority of data are of high quality. Another source for errors is given by the transmission of data from the questionnaire to the electronically manipulable spreadsheet. An error, that can be statistically described and quantified is a measurement bias. When taking a subsample of a large number of realizations, one may by chance pick a set of observations with a mean different from the total. We can, however, at least quantify the bias and the probability, that a randomly chosen subsample will yield a mean in the vicinity of the mean of the total. As employment costs are distributed 
lognormally, we find that the growth rate of employment costs follows a normal distribution with given mean and standard deviation,

$$
\ln w_{t} \sim N\left(\mu_{t}, \sigma_{t}^{2}\right) \Leftrightarrow \frac{w_{t+1}-w_{t}}{w_{t}} \approx \ln w_{t+1}-\ln w_{t} \sim N\left(\mu_{t+1}-\mu_{t}, \sigma^{2}\right) .
$$

We can use the sample variance as an unbiased point estimator for the true variance. With (1- $\alpha / 2) \%$ certainty, the observed employment cost will be within the following interval,

$$
[\underline{\mu}, \bar{\mu}]=\left(\ln w_{t+1}-\ln w_{t}\right) \pm \frac{s}{\sqrt{n}} t_{n-1,1-\alpha / 2},
$$

where $\mathrm{n}$ is the number of observations in the sample and $\mathrm{s}$ is the sample standard deviation. The length of the interval is then equal to,

$$
d=2 \frac{s}{\sqrt{n}} t_{n-1,1-\alpha / 2} \text {. }
$$

If we want $d$ to take a specific distance, we can derive the required sample size, which equals,

$$
n=\left(\frac{2 s}{d} t_{n-1,1-\alpha / 2}\right)^{2} \approx\left(\frac{2 s}{d} u_{1-\alpha / 2}\right)^{2},
$$

where the approximation holds for more than 20 observations. $u$ follows the standard normal distribution. We found that only 228 observations are required to obtain an aggregate EEPI for Austria within +/- one percentage point at the $95 \%$ significance level. If one wants to get specific indices by profession, 1490 observations are required. A regional division in NUTS requires only 596 observations, and even a division by province only takes 1085 , so that a subindex by province can be provided at zero costs. The low number of observation for the aggregate sample is due to the fact that the variance does not increase much across sectors, states or professions, so that the measurement bias can be held small. For the six sectors in the pilot survey, we require a sample size of 1315 observations. As there are 22 sectors to be included in the first stage of the EEPI a sectoral subdivision requires 4822 observations.

\section{Main Empirical Results}

The following table presents cross statistics for growth rates of EEPI cost categories and sectors, as well as for the Austrian aggregate. The EEPI increased for all sectors and hence for the Austrian aggregate, too. However, most of the increase is in construction, electrical supply, textiles, and tourism, which is due to the fact that collective bargaining wage raises came into effect between the two months of observation. 


\begin{tabular}{l|rrrrrrr} 
Cost Category & Sector \\
\hline Change in \% & Construction & El. Supply Finance & Engineer. Textiles & Tourism & Austria \\
\hline Gross wages & 6,60 & 7,13 & 0,61 & 2,96 & 5,52 & 2,50 & 4,30 \\
Premium pay and bonuses & 8,42 & 11,36 & 0,41 & $-5,36$ & 1,54 & $-0,15$ & 2,82 \\
Allowance for work performed outside normal & $-15,67$ & $-0,08$ & 0,35 & $-0,89$ & 16,16 & 0,30 & $-4,78$ \\
working hours & & & & & & & \\
Bonuses linked to results or performance not paid & $-1,57$ & 24,11 & 1,12 & $-19,61$ & 5,15 & 0,00 & $-0,05$ \\
at each period & & & & & & & \\
Other bonuses not paid at each period & 14,61 & 17,93 & 0,07 & $-5,97$ & 0,00 & $-0,36$ & 5,81 \\
Benefits in kind & 0,00 & 0,00 & 0,00 & 0,00 & $-0,95$ & 0,00 & 0,00 \\
Payments for days not worked & $-0,97$ & 4,36 & $-1,31$ & $-6,32$ & 0,39 & 5,34 & 0,71 \\
Payments to employees savings schemes & 0,00 & 0,00 & 0,00 & 0,00 & 0,00 & 0,00 & 0,00 \\
Employer's share of statutory social security & 3,99 & 0,77 & $-0,29$ & $-1,10$ & 1,22 & 5,92 & 2,06 \\
Pensions & 1,86 & 0,00 & 0,00 & $-0,30$ & 0,05 & 0,00 & 0,58 \\
Sickness & 1,92 & 0,00 & 0,00 & $-0,39$ & 0,05 & 0,00 & 0,62 \\
Unemployment & 1,87 & 0,00 & 0,00 & $-0,37$ & 0,05 & 0,00 & 0,58 \\
Other statutory contributions & 7,81 & 2,36 & $-0,95$ & $-2,44$ & 3,26 & 19,91 & 5,09 \\
Employer's share of non-statutory social & $-15,12$ & 0,01 & $-0,23$ & 0,00 & 0,00 & 3,66 & $-0,28$ \\
security & & & & & & & \\
Supplementary pension schemes & $-100,00$ & 0,03 & 0,00 & 0,00 & 0,00 & 3,66 & $-0,10$ \\
Supplementary sickness insurance schemes & 0,00 & 0,00 & $-0,53$ & 0,00 & 0,00 & 0,00 & $-0,51$ \\
Supplementary unemployment insurance schemes & 0,00 & 0,00 & 0,00 & 0,00 & 0,00 & 0,00 & 0,00 \\
Direct social benefits & 0,63 & 4,02 & $-0,03$ & $-0,40$ & 0,06 & $-0,48$ & 0,24 \\
Supplementary daily allowance for sickness & 0,00 & 0,00 & 0,00 & 0,00 & 0,00 & 0,00 & 0,00 \\
Other direct social benefits & 0,63 & 4,02 & $-0,03$ & $-0,40$ & 0,06 & $-0,48$ & 0,24 \\
Payroll taxes & 6,94 & 2,06 & $-0,58$ & $-6,19$ & 3,07 & 23,82 & 4,79 \\
Total compensation & 6,22 & 6,34 & 0,32 & 0,19 & 3,99 & 2,71 & 3,37 \\
\hline Measurement Error in \% & 2,13 & 6,80 & 3,46 & 2,66 & 2,07 & 4,27 & 0,92
\end{tabular}

As the study was not aimed at obtaining a correct EEPI for all categories, but to analyze the feasibility of implementation, a disclaimer to the previous table is in place. The last line in the preceding table indicates the measurement error to the $95 \%$ significance level. We find that except for the aggregate, the realization may lie within rather wide margins of at least $+/-2$ percentage points, the data therefore exhibit only little statistical significance. Several specific cost categories, in particular payments to employment savings schemes, supplementary unemployment insurance, and supplementary allowances for sickness were not paid any case, leaving a large scope of error. Robustness of the data were additionally affected as other cells had very few observations ${ }^{8}$.

The first analytical questions that arises is whether the sectoral, regional, and professional structure is purposeful. For that, we have tested the joint null hypothesis, $\mathrm{H}_{0}: \beta=0$, for insignificance of sectoral dummies, regional dummies, and professional dummies to explain employment costs per standardized hour (TC). After estimating the unconstrained model,

$$
T C=\alpha+\beta D+\gamma X,
$$

were $\alpha$ is a constant, $\beta$ is a vector of parameters for the explanatory variable matrix $D$, and $\gamma$ is the parameter vector for the set of control variables contained in the matrix X. If we wanted to test the significance of a sectoral distinction, e.g., we have used the regional and professional dummies as control variables for the following reason. ${ }^{9}$ Imposing the restriction $\beta=0$ on the model, we have estimated the restricted model. The statistic

$$
F=\frac{\left(R S S_{R}-R S S_{U R}\right) / m}{R S S_{U R} /(n-k)}
$$


follows the $\mathrm{F}$ distribution with $\mathrm{m},(\mathrm{n}-\mathrm{k}) \mathrm{df}$, where $\mathrm{m}$ is the number of linear restrictions, $\mathrm{k}$ is the number of parameters in the unrestricted regression, $\mathrm{n}$ is the number of observations (271), RSS is the residual sum of squares for the restricted (R) and unrestricted (UR) model, respectively. The following table reports the observed result and the critical $\mathrm{F}(\mathrm{m}, \mathrm{n}-\mathrm{k})$ statistic at the $95 \%$ significance level. The null hypothesis is accepted if and only if the estimation result is below the $\mathrm{F}$ value.

\begin{tabular}{lrrrr} 
Hypothesis & $\boldsymbol{m}$ & $\boldsymbol{k}$ & observed $\boldsymbol{F}$ & critical $\boldsymbol{F}(\boldsymbol{m}, \boldsymbol{n}-\boldsymbol{k})$ \\
\hline Regional Dummies insignificant & 5 & 18 & 1,58 & 4,39 \\
Sectoral Dummies insignificant & 5 & 18 & 0,41 & 4,39 \\
Professional Dummies insignificant & 7 & 18 & 0,79 & 3,25
\end{tabular}

The null hypothesis is rejected for all three restrictions. This implies that the sectoral, regional, and professional distinction is significant, at least for some observations. Relaxing the constraints, which is not reported here, we find that for the sectors, only financial intermediation and tourism are distinct from the others. Note that amongst the regions in the sample, only Vienna is different from other provinces, whilst all professions are distinct. However, the explanatory power of all the regressions is weak, suggesting that other factors outside the EEPI may be influential for employment costs.

We tried next to check whether one could retrieve the information of the EEPI from a subsample of the data alone. For this purpose, we regressed growth rates of the cost categories and total compensation minus gross wages on the growth rate of gross wages. The EEPI cannot rely upon a subsample of costs to produce an accurate index of employment costs.

The sample has also been used to test some of the hypothesis of the survey. We tested whether the size of a company is relevant for employment costs by regressing the number of employees (E) of the firm on every workers total compensation per standardized hour,

$$
T C=330,944+0,020 E .
$$

A t-statistic of 0,90 suggests no significant influence of the company size on employment costs in our sample. Similarly, we find that the permanency (P) of the work contract has no significant influence on total compensation, as

$$
T C=346,250-67,788 \text { non } P-264,298 A .
$$

Note however, that apprentices (A), who have been in the sample as well, do earn significantly less than the rest of the workforce. Finally, part-time workers (PT) are also paid significantly less than the rest of the workforce,

$$
T C=333,027-102,619 P T,
$$

which may be due to the large number of women in that group.

\section{Conclusions}

It is possible to establish a Laspeyres index of the momentaneous demand-side transaction price of the standardized unit of labor for Austria, using the particular 
profession as an elementary unit. This index, labeled European Employment Price Index (EEPI), will be distinct from existing indicators of employment costs, and will be preferable for several applications. The EEPI correctly appears to be more stable than other wage indicators. Part of the reason is the input measure of productivity. Despite its advantages, the EEPI may suffer from limited acceptance. Firms competing only in domestic markets expressed the opinion that they have little interest in short-term employment cost information of their competitors, which may be due to the fact that the centralized wage negotiations reveal most of the information in advance. When firms or other users of the EEPI try to exploit the information, asymptotical properties imply that it typically requires some 20 observations to draw any conclusions. One may either compute the index backward in time for the last five years, or the cost for the next five years are not confronted by any benefits.

In order to reduce procurement costs, the number of observations should be reduced. First, one should eliminate smaller companies, were data were weak anyhow, and no additional information was gathered. Second, one should reduce the number of sectors involved. As only export or import oriented sectors would have an interest in a European-wide index of employment costs, the survey should only cover those. Third, one may initiate the index only for the aggregate series, holding the sample size low.

\section{Acknowledgments}

This article is based on a larger study of the Ludwig Boltzmann Institute for Growth Research by the order of Eurostat and ÖSTAT. We would like to thank our co-authors on other chapters of the study, Herbert Walther, Alois Guger, Christian Ragacs and the six participating research students. We have benefited from comments and suggestions of Derek Bird, Louis DeMarcillac, Margit Epler, Alois Franz, Günther Herget, and Kurt Pratscher.

\section{Endnotes}

${ }^{1}$ The EEPI adheres to the standardised hour as the basic unit of employment costs, holding the composition of hours associated with different costs over time constant. We have to distinguish between costs that are related to specific working hours, such as overtime and sickness, and costs that are not. Standardisation is achieved by relating costs to normal working hours, defined as normal working hours in the base year plus overtime hours minus the number of hours not worked in the base year.

${ }^{2}$ It is a demand-price as it does include all types of costs, which the demand side for labour, in particular firms, have to pay, and does not measure net receipts of the supply side. It is a transaction price (or implicit spot market price) of labour, as all costs that accrue instantly as well as all costs that will arise in the future shall be included. The EEPI is standardised to the unit of labour services, by separating price effects from quantity effects in the measurement of labour costs.

${ }^{3}$ The enormous volatility of other employment cost indicators, may induce some negative macroeconomic consequences in the case of not fully rational firms and 
investors. The channel may run as follows: An increase in employment costs, as signalled by any employment cost index induces investors to assume that company profits will decline. This implies a decrease in the rate of return. As investment correlates negatively with the rate of return, this in turn induces low real investment whenever employment costs increase. A volatile measure of employment costs therefore induces a more volatile business cycle.

${ }^{4}$ In most cases, the unit wage costs are used as the benchmark case. Unit wage costs are commonly defined as the quotient of the nominal wage sum (according to national accounts) and nominal GDP, and measures wage costs per unit of output.

${ }^{5}$ Note that unit wage costs could also be defined as wages times the inverse of labour productivity (i.e. Output per unit of employment).

${ }^{6}$ Granger-causality tests show, however, that the EEPI will only serve this purpose at the European level, whilst little information can be obtained for Austrian monetary policy. See Ragacs, Walther, and Zagler (1998) for details.

${ }^{7}$ For the weights, we used data of the 1995 microcensus, which has the number of employees separated by province, sector and occupation. Unfortunately, no distinction could be made for age, termination of labour contract or part-time employment, as intended by the concept for the EECI. The advantage of using this secondary source was the larger size of the sample.

${ }^{8}$ Note that we report a $100 \%$ decline in the category supplementary pension schemes in construction, due to the fact that contributions (temporarily) ceased for the one and only individual.

${ }^{9}$ Assume for example that due to an increase in costs of living, employment costs increase in Vorarlberg. Then we would also observe an increase in employment costs in the textile sector, as it is mainly located there.

\section{References}

D.N. Gujarati. Basic Econometrics. Third Edition, New York: McGraw-Hill International Editions, 1995.

R. Hafner. Statistik für Sozial- und Wirtschaftswissenschafter. Wien: Springer, 1992.

B.R. Moulton. Bias in the Consumer Price Index: What is the Evidence? Journal of Economic Perspectives 10, 159 - 177, 1996.

Ch. Ragacs, H. Walther, M. Zagler. Monetary Policy, Cost-Push Inflation and the European Employment Price Index. Vienna: mimeo, 1998.

J. Triplett (ed.). The Measurement of Labor Costs. Chicago: Univ. of Chicago Press, 1983.

M. Zagler, H. Walther, A. Guger, U. Mühlberger, Ch. Ragacs. The European Employment Cost Index. Implementation and Feasibility Study for Austria. Vienna: Ludwig Boltzmann Institute for Growth Research, 1997. 
Authors' addresses:

Martin Zagler

Vienna University of Economics \& B.A.

Augasse 2-6

A - 1090 Vienna

Austria

Tel. +43 $131336 / 4016$

Fax +43131336/ 728

E-mail: Zagler@isis.wu-wien.ac.at

Web: http://www.wu-wien.ac.at/inst/vw1/zagler/

Ulrike Mühlberger

European University Institute

Badia Fiesolana

Via dei Roccettini, 9

I - 50016 S. Domenico di Fiesole (FI)

Italy 